\title{
Forecasting Uncertainty and Risk of Financial Development in Pakistan: Fan Chart Approach
}

\author{
Muhammad Nadeem Khan *
}

\begin{abstract}
This study is conducted to forecast the components of financial development of Pakistan for the period of 2016 to 2025. These components include M2, DCP, DCPB, and MC. Originally, 36 years' time series data taken from 1980 to 2015. The present study is very much different in that it uses a newly developed technique that is Fan chart. It is used to forecast with given level of uncertainty. Risk information of upside and downside is another feature of fan chart approach. The results of $\mathrm{M} 2$ indicate that, downside risk at the start of forecasting in the year of 2016 initially, but after that it will start upside risk in the reaming period of 2017 to highest value in 2025. This shows that, chances of increase in value of M2 in the upcoming forecasted period. On the other side forecasted value of DCP will have an upside risk during the all period. Whereas, value of DCPB indicates a downside risk in the all forecasted period of 2016 to 2025. At the same time, value of $M C$ has a downside risk in the all-time period. On the basis of these findings, it is recommended to policy makers to keep a diligent eye on risk uncertainty. Downside risk is an alarming situation in the coming years or the uncertainty around to the extent of that change. Upside risk should also be considered by the policy maker to make better decisions.
\end{abstract}

Keywords: Forecasting, uncertainty, risk, financial development, fan chart.

\section{Introduction and Literature Review}

Financial development is a cost of obtaining information, administration of agreements and facilitation of financial transactions for the development of actual forms of financial contracts, markets and intermediaries (Levine, 2005). It includes institutions, policy, macroeconomic factors and to some extent legal and regulatory framework that allows extended credit to private sector. It is basically, overcoming "costs" that is the part of financial system. When that happens, then the cost of getting information, contracts implementation, financial transaction and other related costs reduced. Recently, financial matters have been improved interest significantly among the other developments. It is also putting developing commitments on the part of economic frameworks in financial development. Research on the part of financial progress in development can be followed back by Bagehot (1873) who emphasizes that vast and efficient capital markets in England improved asset distribution towards more beneficial project. Developing nations that had been meeting surges in for-

\footnotetext{
* Department of Business Administration, IQRA University, Karachi, Pakistan.

E-mail: khan.i@iuk.edu.pk

This paper is a part of Muhammad Nadeem Khan's Ph.D. Dissertation
} 
eign capital inflows have needed to encounter a decrease in a similar capital inflow amid the current international financial crisis (Kose, Prasad, \& Taylor, 2009). Uncertainty in financial streams has restored the long-standing verbal confrontation about whether the benefits of recent financial structure far offset their development reliefs (Rodrik \& Subramanian, 2009).

Many studies have been conducted in the financial development to check the uncertainty and risk. Holod, Kitsul, and Torna (2017) investigated the mitigation of the bank risk that was linked with the activities of trading if the capital requirements of the market risk based that was implemented in the year 1998. Valencia (2017) attempted to investigate and propose a capital channel of bank through which shocks of uncertainty can impact the fluctuations in macroeconomic variables. The author had first presented a dynamic model of bank in which a mechanism of self-insurance contributed towards inducing the bank in order to accumulate the capital with the increase in uncertainty. Asongu, Koomson, and Tchamyou (2017) examined the impact of time-dynamic uncertainty globalization in the financial institutions on the development of financial sector in total 53 nations of Africa for the years 2000 to the year 2011. Caldara, Fuentes-Albero, Gilchrist, and Zakrajšek (2016) had utilized an approach of penalty function within the framework of structural vector autoregressive (SVAR) for the purpose of examining the association between uncertainty in the economy and conditions of financial intermediaries as well as to examine the effect of these shocks to the economy of the nations. The findings of this research study showed that shocks in the financial institutions have a significant and adverse impact on the different outcomes of the economy and also that these shocks are key sources of the fluctuations in the business cycles since after the year 1980. Kitagawa and Okuda (2016) examined the forecasting in the management, idiosyncratic risk as well as environment of the information due to the fact that management forecast are considered to be a key source of the information in the stock market of Japan. The authors in this research study had utilized an error of management forecast as a proxy variable for the quality of disclosure as well as idiosyncratic risk. Black, Correa, Huang, and Zhou (2016) had measured the systematic risks of the banks of Europe due to the fact that banks of Europe have become a key risk source to the financial markets of the world during the crisis in the financial markets as well as attention to the sector of banking has increased during the crisis of sovereign debt. One of the interesting results of the findings is that, traditional ratio of the capital adequacy as well as implicit support of the government resulted in the increase in systematic risk. Bekaert, Hoerova, and Duca (2013) attempted to propose a first and important characterization of the dynamic association between uncertainty of risk as well as monetary policy through utilizing the framework of simple autoregressive model. Research study by Moshirian (2011) attempted to analyze the global crisis in the financial sector with regard to the different processes of the development in market as well as regulations. This paper discussed that in the absence of the framework of financial market that was integrated globally, by the past and regulations in the present time period in reaction to the global as well as national financial crisis failed to resolve the cross border arbitrage of the regulations. Bloom, Bond, and Van Reenen (2007) indicated that with the inclusion of partial irreversibility, uncertainty contributed toward reducing the investment's responsiveness to the shocks of demand. 
A number of studies have also been conducted in Pakistan linked financial development with economic development, growth, and energy consumption. Rizwan-ul Hassan, Imam, and Salim (2017) analysis the impact of financial development on economic growth in Pakistan. Javid and Sharif (2016) investigate the relationship of environmental Kuznets curve and financial development in Pakistan. Komal and Abbas (2015) examine the linkage of economic growth, financial development and energy consumption in Pakistan. Kakar, Khilji, and Khan (2011) also examine the empirical relationship of financial development and energy consumption in Pakistan. Abbasi and Riaz (2016) pointed the relationship of influence of economic and financial development on $\mathrm{CO} 2$ emission in the context of an emerging economy of Pakistan. Gokmenoglu, Amin, and Taspinar (2015) found the longrun relationship among financial development, international trade and economic growth in Pakistan. Shahbaz and Rahman (2012) investigate the dynamics of financial development, imports, foreign direct investment and economic growth in Pakistan. Khan, Qayyum, Sheikh, and Siddique (2005) discussed the relationship between the financial depth and economic growth both in short and long-run. Shahbaz, Ahmed, and Ali (2008) find the relationship of stock market development and economic growth in Pakistan. Developing countries also facing financial constraints, due to restrictions of giving loan imposed by the banks to their favorable groups of investors and companies (Shahbaz et al., 2008).

The above mentioned discussion of the literatures follows two approaches. The first approach estimates bank risk that was linked with market risks, association between uncertainty and financial intermediaries, the effects of these shocks to the economy of the country, and also time-dynamic uncertainty globalization in the financial institutions (Holod et al., 2017; Valencia, 2017; Asongu et al., 2017; Kitagawa \& Okuda, 2016; Bekaert et al., 2013). Whereas, the second approach estimates the relationship between financial development, economic growth, and energy consumption by using the conventional unit root test, cointegration and causality tests (Rizwan-ul Hassan et al., 2017; Javid \& Sharif, 2016; Komal \& Abbas, 2015; Kakar et al., 2011; Abbasi \& Riaz, 2016; Gokmenoglu et al., 2015; Shahbaz et al., 2008; Shahbaz \& Rahman, 2012). As these studies found that, financial development has significant impact on economic development and it is also seen that financial institutions play very important role in distribution and allocation of finance to different sectors of economy, which encourage economic activity. Preceding discussion in two approaches were all about to cover different features of financial development, but it had never been forecasted to see that how will be the financial services industry progress over the next decade is the substance of this study. Therefore, the objective of this study is to forecast the components of financial development of Pakistan for the period of 2016 to 2025. In time series analysis Autoregressive Integrated Moving Average (ARIMA) is used to forecast future trends. In ARIMA forecasting, residual uncertainty is considered, whereas uncertainty in parameters is overlooked (Fuller \& Hasza, 1981; De Luna, 2000). On the contrary, density forecast contemplates parameters' uncertainty (Akram, Binning, \& Maih, 2016). The present study is very much different in that it uses a newly developed technique that is Fan chart. It is used to forecast with given level of range of uncertainty. Forecasting can be done by some other methods such as moving average and exponential smoothing but, Fan chart results provides range of uncertainties that would be useful to make favorable strategies for policy makers. Recently, Castillo (2016); Dowd, Blake, and 
Cairns (2016); Jawaid, Waheed, et al. (2017); Fukač and Kirkby (2017) used for forecasting this newly developed Fan chart technique.

\section{Data and Methodology}

This study is conducted to forecast the components of financial development of Pakistan for the period of 2016 to 2025. These components include M2, DCP, DCPB, and MC. Originally, 36 years' time series data taken from 1980 to 2015. All these data taken from the World Development Indicators (WDI), and from Handbook of Statistics of Pakistan. Software used to run the fan chart is Eviews-9.

\section{Contextual Discussion- Measuring Financial Development}

Financial crisis of 2008 is considered to be the worst disaster since 1930 of the Great Depression. It was seen the failure of financial giants like Lemhan Brothers, Bears Stearms etc. It was results of series of mortgage crisis occurred at that time. Different channels spread the crisis through financial incorporation and trade (Latif, Nazar, Shah, \& Shaikh, 2011). During the previous few years, numerous countries have undergone serious cash and saving money emergencies, creating an amazing toll on their economies, especially in developing countries business sector. In many time, the banking sector keeping money more than 20 percent of GDP and output decreases in the wake of emergency have been as large as 14 percent (Reinhart, 2000). Worldwide Financial Crisis troubled Pakistan's financial development to some extent. Pakistan faces foremost of accomplishing macroeconomic consistency and pushing economy on track. Worldwide Financial Crisis has brought consideration towards numerous issues. Thus, there is a great deal of study required in financial development of Pakistan.

This part of study starts from little explanation of the components of financial development. Many researchers used money supply as financial sector depth (Giedeman, Compton, et al., 2009; Anwar \& Cooray, 2012). In addition to money supply several researchers also used ratio of domestic credit to private sector to GDP as measures of financial activities (Beck \& Levine, 2004; Cole, Moshirian, \& Wu, 2008). After these two primary measures, the effect of stock market also considered as an important tool of financial development (Atje \& Jovanovic, 1993). The most common proxy used for stock market development is market capitalization ratio (Shen \& Lee, 2006; Chakraborty, 2010; J.-S. Yu, Hassan, \& Sanchez, 2012). Therefore, in this study these financial development measures used namely broad money supply (M2), domestic credit to private sector (DCP) domestic credit to private sector by banks (DCPB), and market capitalization (MC). Reason for selection of these variables are availability of data and also importance of these variables very vital for an emerging country such as Pakistan's economy.

\section{Broad Money Supply (M2)}

Three types of monetary combinations are used in Pakistan to measure and formulate money related policies. These three types include namely M0, M1 and M2. The M2 is 
also known as broader money supply, which includes physical currency in circulation, time deposits, demand deposits, other deposits, and resident foreign currency deposits in the scheduled banks (Hussain, 2005). M2 is the oldest and the most efficient measure used in financial development by Sehrawat and Giri (2017); Adu, Marbuah, and Mensah (2013); Nik, Nasab, Salmani, and Shahriari (2013); Hsueh, Hu, and Tu (2013); Outreville (1999). 36 years' M2 data of Pakistan has been used as a percentage of GDP from 1980 to 2015. In 1980 it was $41.50 \%$ to $53.32 \%$ in 2015 . It shows $28.49 \%$ increase in broad money supply during the period of 36 years. Its highest value during the 36 past years was 56.37 in 2007 , whereas, lowest value was 38.60 in 2000 .

\section{Figure 1}

Broad Money Supply (\% of GDP) in Pakistan from year 1980 to 2015

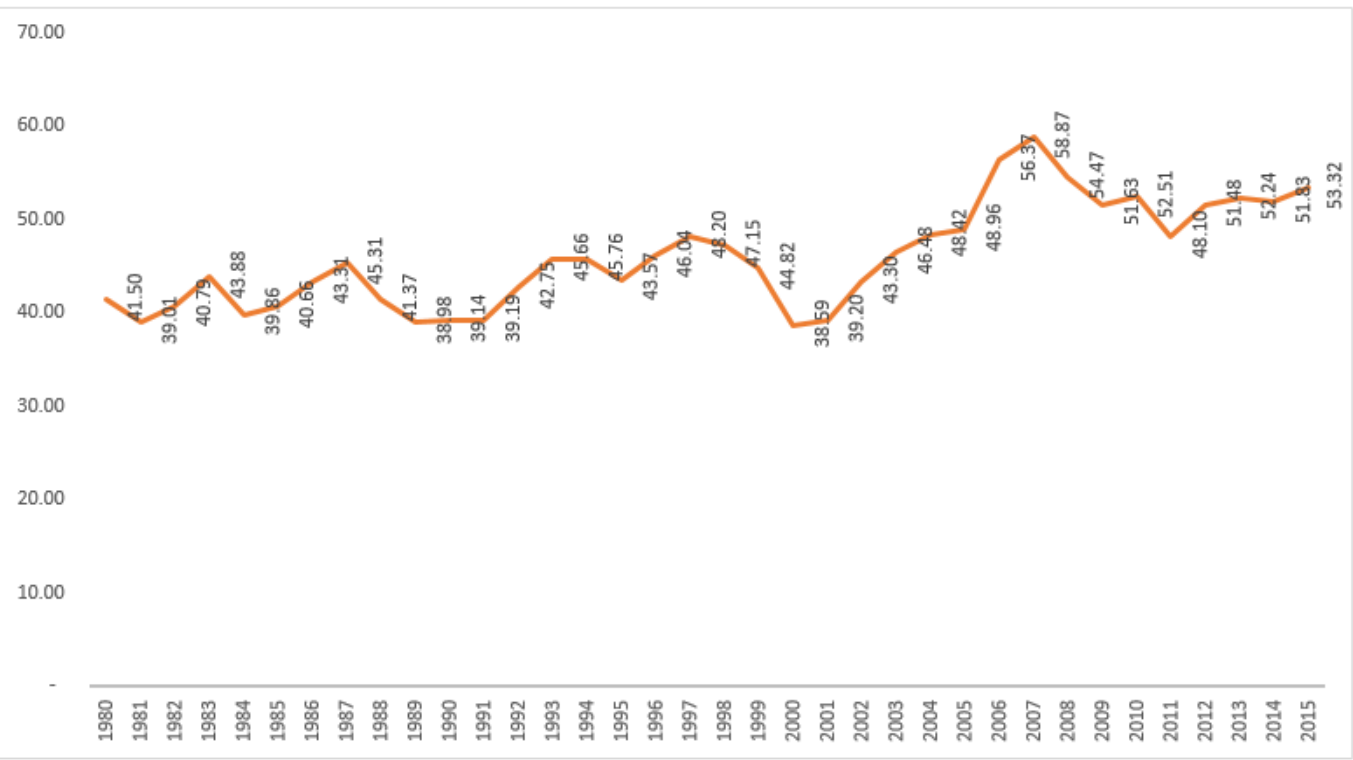

Source: Authors' Construction

\section{Domestic Credit to Private Sector (DCP)}

This financial development measure (DCP) refers to financial assets provided to the private sector, which includes loans, purchasing of non-equity security, receivables and trade credits. DCP is the total credit amount of a country obtain by the private sector from financial institutions. Financial institutions include all sorts of monetary authorities such as banks, leasing companies, money lenders, insurance companies, pension funds and foreign exchange companies. DCP used by Sehrawat and Giri (2017); Duarte, Kedong, and Xuemei (2017); Mahmood (2013); Nik et al. (2013); Hakeem and Oluitan (2012). 36 years' data taken from 1980 to 2015 . The highest value of DCP was 28.74 in 2004, whereas the lowest value was 15.39 in 2015. Average value of DCP was 23.88 during 36 years' period. 


\section{Figure 2}

Domestic credit to private sector (\% of GDP) in Pakistan from year 1980 to 2015

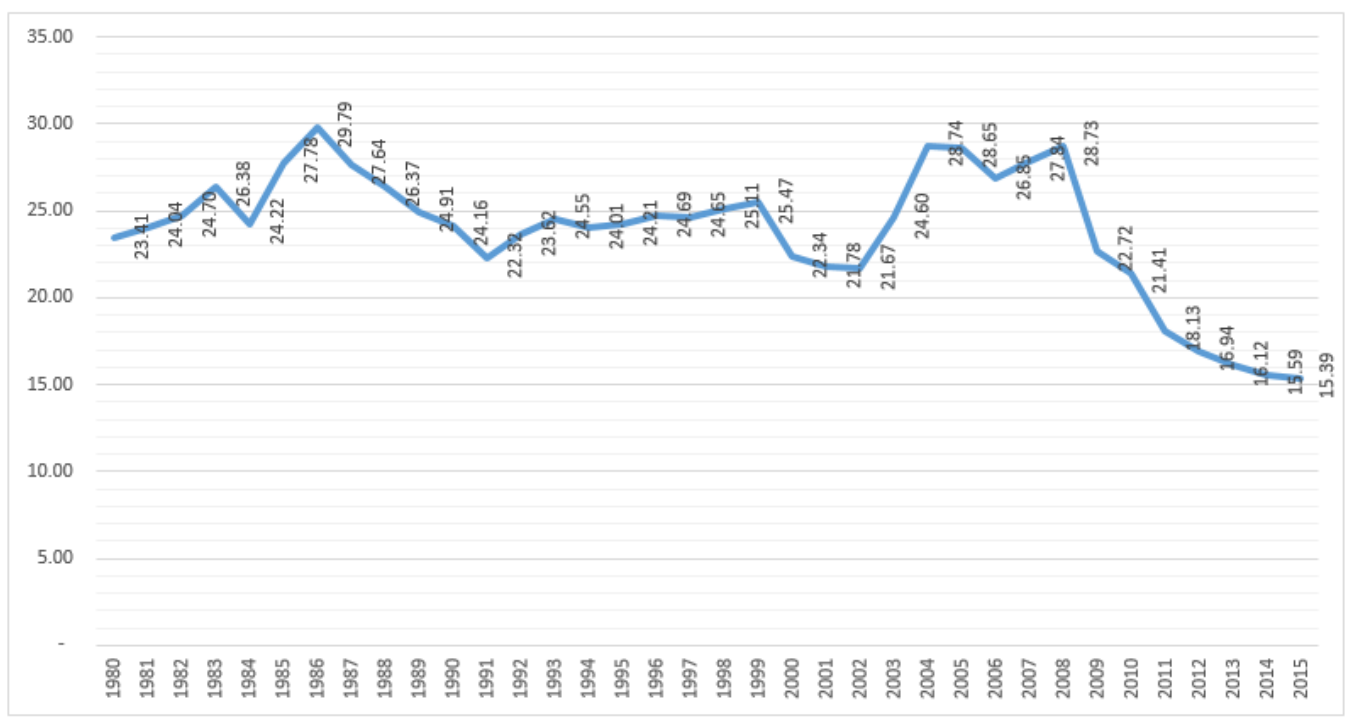

Source: Authors' Construction

\section{Domestic Credit to Private Sector by Banks (DCPB)}

Another measure of financial development is domestic credit to private sector by bank as a percentage of GDP (DCPB). It refers to the resources provided by other depository institutions except central banks. Its value very much close to DCP, but sometimes DCPB value changes due to different resources used to calculate the value. DCPB used by Sehrawat and Giri (2017); Nik et al. (2013); Mahmood (2013). 36 years' annual data from 1980 to 2015 used to forecast the financial development of Pakistan. DCPB highest value was 28.74 in 2004 and the lowest value was 15.31 in 2015 .

\section{Market Capitalization (MC)}

Market capitalization is another measure of assessing the financial development in the country. It represents the total value of all the outstanding stocks based on current market price. Calculation is based on current market price multiply with the company's shares outstanding. Atje and Jovanovic (1993) started to investigate the stock market as financial development measure in country. After that proxy of stock market have been using as market capitalization (MC) by Shen and Lee (2006); Chakraborty (2010); Valickova, Havranek, and Horvath (2015); J.-S. Yu et al. (2012). 


\section{Figure 3}

Domestic credit to private sector by banks (\% of GDP) in Pakistan from year 1980 to 2015

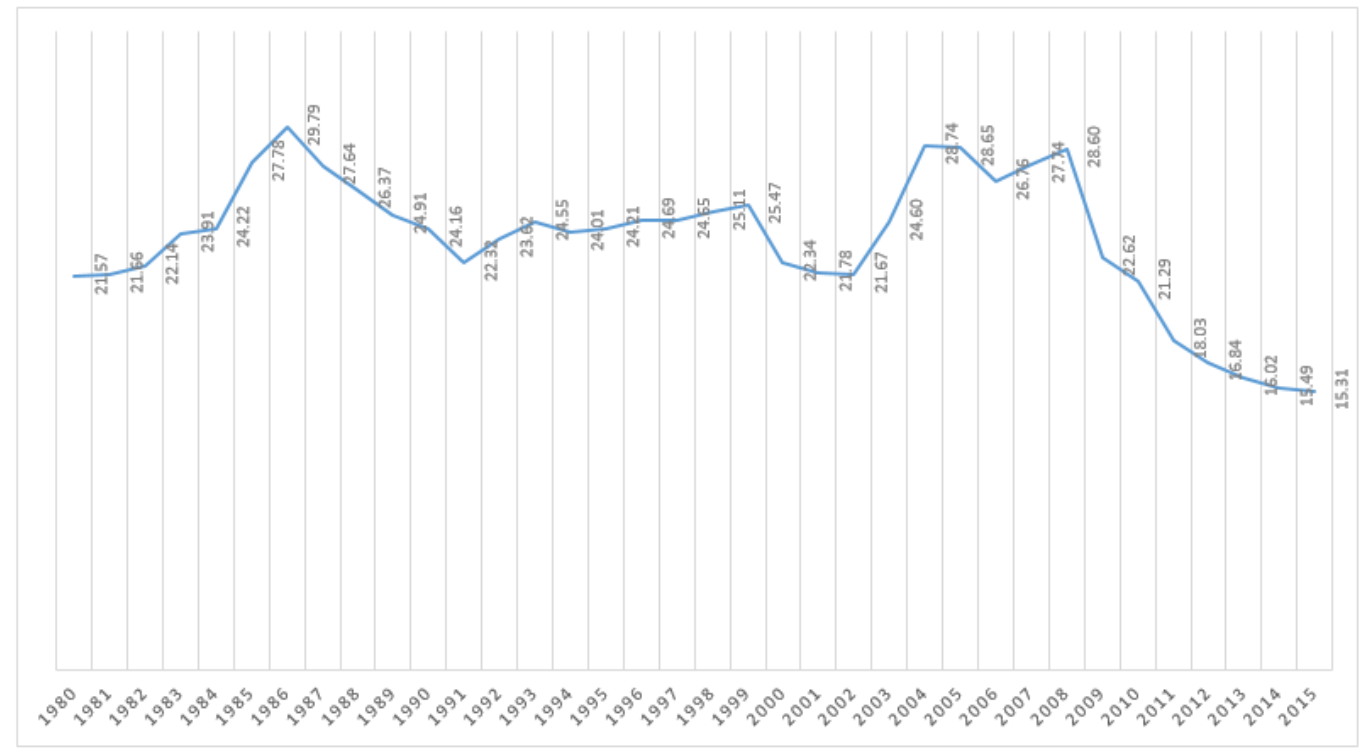

Source: Authors' Construction

MC value of Pakistan Stock Exchange (PSE) was taken from 1993 to 2015. The major issue of selecting this time period is the availability of data. MC value starting from Rs. 355,604 million was in 1993 to move up to Rs. 7,421,032 million in 2015. During of this period, it has been almost $2000 \%$ increase in the value of market capitalization of PSE.

PSE is considered smaller in size but very significant and more active stock market than other stock market globally. In 2002 PSE stand as the best performing stock market. One of the reason of this, recent political and macroeconomic improvements are considered to expand market liquidity and give higher capital additions to speculators. The other view is that this abnormal state of exchanging is revealing of short term dealers who exploit a rare carry forward exchanging course of action (Iqbal, 2012).

\section{Fan Chart}

Economic forecasting generally faces the issue of vulnerability. It's not possible for anyone to anticipate forthcoming activities with perfect confidence, since it is constantly certain in various expectations and a range of positive and negative threats. The reservation is one of the crucial reasons of poor results and which may be the key cause of disappointments in forecasting. In spite of the fact that estimating philosophies have grown mostly, the issue of insecurity has not been settled in financial forecasting. 


\section{Figure 4}

Market capitalization in Pakistan from year 1993 to 2015

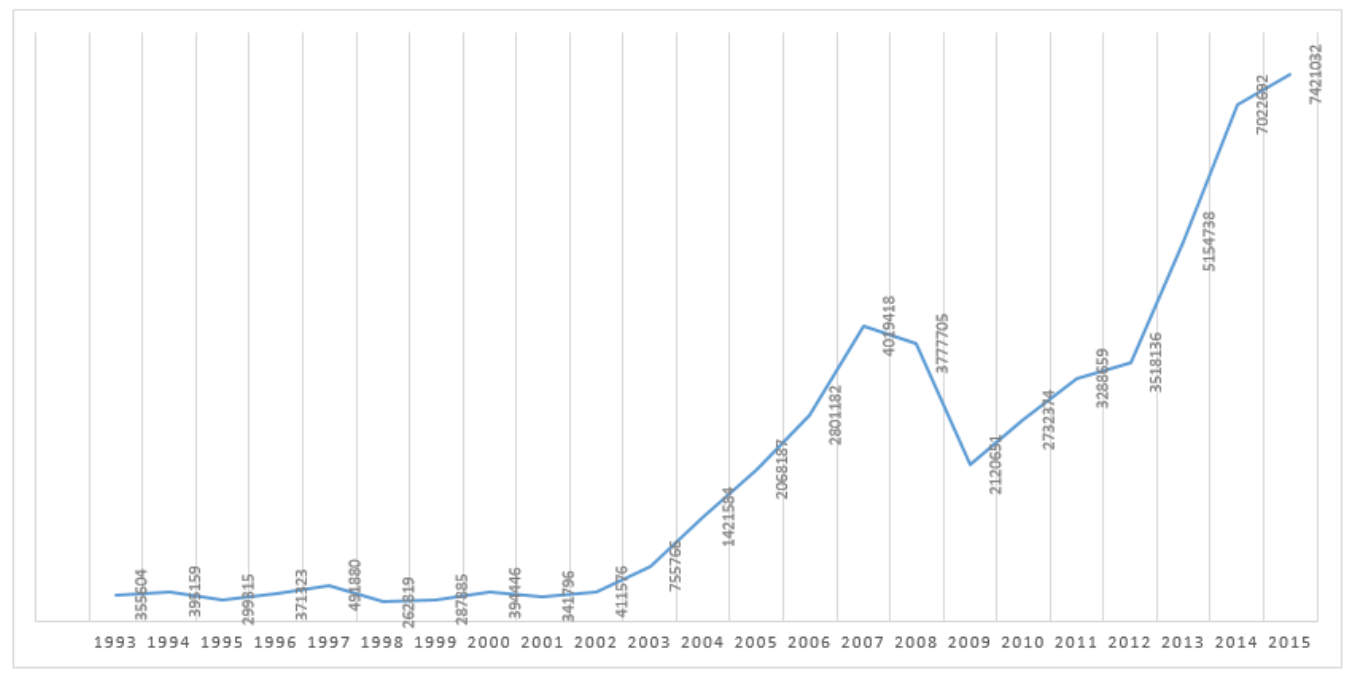

Source: Authors' Construction

Fan chart technique is useful for making economic forecasting, and it was first time used in monetary policy of Bank of England for inflation prediction published in 1963. Subsequently, usefulness of fan chart has been increased in forecasting other economic elements such as predicting of GDP growth rate and other indicators. Similarly, fan chart has also been used for forecasting of world economic growth by international monetary fund (IMF) since 2006. In Pakistan, Jawaid et al. (2017) have used the same method for forecasting Pakistan's regional trade. Accordingly, in this study we used fan chart technique (Kannan \& Elekdag, 2009) for forecasting of growth in components of financial development (M2, DCP, DCPB, and MC) for the period of 2016 to 2025.

Steps involve in constructing of fan chart for growth of components of FDI are as follows:

1. Calculation of growth estimate for M2, DCP, DCPB, and MC (denoted as $\pi$ )

2. Parameter of uncertainty is calculated as historic estimate error variance (indicated by $\left.\epsilon_{\pi}\right)$

3. Pearson Skewness indicator is calculated (denoted as $\Omega_{\pi}$ ) for construction of skewed fan chart

4. The confidence level $(\mu)$ i.e. 90 percent, 60 percent and 30 percent used to be revealed in the fan chart.

5. Established parameters are known as Skewness $\left(\Omega_{\pi}\right)$ and variance $\left(\epsilon_{\pi}\right)$, which categorized distribution of factors of the 2 portion normal spreading i.e. the mean $(\mu)$ 
which signifies the dominant calculation and the left-hand and right-hand average deviation as $\left(\partial_{1}\right.$ and $\left.\partial_{2}\right)$ respectively for the said distribution.

Moreover, function of density of 2-piece normal distribution is presented as follows: Identical mean $(\mu)$ and changed deviations $\left(\partial_{1}\right.$ and $\left.\partial_{2}\right)$ arranged separate side is presented as:

$$
\begin{aligned}
& f(\pi)=Z \exp \left\{-\frac{(y-\mu)^{2}}{2 \partial_{2}^{2}}\right\} \text { for } \pi \leq \mu \\
& f(\pi)=Z \exp \left\{-\frac{(y-\mu)^{2}}{2 \partial_{2}^{2}}\right\} \text { for } \pi>\mu
\end{aligned}
$$

Where

$$
Z=\frac{\sqrt{2}\left(\partial_{1}+\partial_{2}\right)^{-1}}{\sqrt{\pi}}
$$

At this point $\mu$ denotes the method of spreading if $\lambda \partial_{1} \neq \lambda \partial_{2}$ (i.e. spreading is skewed). Below are the equations which signify mean, variance and Skewness of two-portion standard spreading individually

$$
\begin{gathered}
S(\pi)=\mu+\frac{2}{\pi}\left(\lambda \partial_{1}-\lambda \partial_{2}\right) \\
T(\pi)=\lambda \partial_{1} \lambda \partial_{2}+\left(1-\frac{2}{\pi}\right)\left(\lambda \partial_{2}-\lambda \partial_{1}\right)^{2} \\
\gamma(\pi)=\frac{2}{\pi}\left(\lambda \partial_{2}-\lambda \partial_{1}\right)\left[\left(\frac{4}{\pi}-1\right)\left(\lambda \partial_{2}-\lambda \partial_{1}\right)^{2}+\lambda \partial_{1} \lambda \partial_{2}\right]
\end{gathered}
$$

Where $\mathrm{S}(\pi), \mathrm{T}(\pi)$ and $\gamma(\pi)$ symbolize the mean, variance and skewness of 2 - portion standard spreading individually. Blix and Sellin (1998) explained the skewness of 2- portion standard distribution, which is calculated as follows:

$$
\gamma(\pi)=\sqrt{\frac{2}{\pi}}\left(\lambda \partial_{2}-\lambda \partial_{1}\right)
$$

For construction of fan chart, the idea of Skewness of 2- section standard spreading make simpler calculation of $\lambda \partial_{1}$ and $\lambda \partial_{2}$. Next, value of $\lambda \partial_{1}$ and $\lambda \partial_{2}$ can be found from $\mathrm{T}(\pi)$ and $\gamma(\pi)$.

By substituting $\lambda \partial_{1}$ in with $\mathrm{T}(\pi)$ and $\lambda \partial_{2}$ with $\gamma(\pi)$ we find the following equation:

$$
\lambda \partial_{1}^{2}+\sqrt{\frac{2}{\pi}} \gamma_{y} \lambda \partial_{1}-\left[\left(1-\frac{\pi}{2}\right) \gamma_{y}^{2}+\lambda \partial_{y}^{2}\right]=0
$$


In the above equation $g a m m a_{y}$ and $\lambda \partial_{y}$ are used to estimate skewness and variance of 2 - section standard spreading respectively. After determining of $\lambda \partial_{1}$ the other side of the standard deviation $\lambda \partial_{1}$ can be defined as follows:

$$
\gamma(y)=\sqrt{\frac{2}{\pi}}\left(\lambda \partial_{2}-\lambda \partial_{1}\right)
$$

6. The nearby confidence interval of each point for M2, DCP, DCPB, and MC growth estimate could be developed for every level of confidence $(\varrho)$, through explaining for

$$
\begin{aligned}
& z_{1}=\mu-\frac{\lambda \partial_{1}}{\lambda \partial_{2}}\left(z_{2}-\mu\right) \\
& z_{2}=\mu-\lambda \partial_{2} \omega^{-1} \frac{1+\varrho}{2}
\end{aligned}
$$

Where $\omega^{-1}\left(0<\omega^{-1}<1\right)$ is the contrary of average standard spreading. Camilleri and Vella (2015); H. Yu (2011) discussed in more detail of these procedures. All the data taken form world bank and handbook of statistics of Pakistan economy.

\section{Empirical Results}

This section provides the data structure, analysis, measurement, characteristics and modeling in order to highlight useful information.

\section{Fan Chart Analysis}

This segment provides the data analysis with respect of forecasting of components of financial development namely M2, DCP, DCPB, and MC in Pakistan.

From Figure 5 and also Table 1 represents the fan chart analysis of M2. It is noticeable that, the average growth rate of M2 during the period of 2016 to 2025 would be 48.76 percent.

Skewness result shows downside risk at the start of forecasting in the year of 2016 initially, but after that it will start upside risk in the reaming period of 2017 to highest

\begin{tabular}{|c|c|c|c|c|c|c|c|c|c|c|c|c|c|c|c|c|c|c|c|c|}
\hline Year & \multicolumn{2}{|c|}{2016} & \multicolumn{2}{|c|}{2017} & \multicolumn{2}{|c|}{2018} & \multicolumn{2}{|c|}{2019} & \multicolumn{2}{|c|}{2020} & \multicolumn{2}{|c|}{2021} & \multicolumn{2}{|c|}{2022} & \multicolumn{2}{|c|}{2023} & \multicolumn{2}{|c|}{2024} & \multicolumn{2}{|c|}{2025} \\
\hline M2 Growth & \multirow{2}{*}{\multicolumn{2}{|c|}{$\begin{array}{r}50.09 \\
-0.076 \\
\end{array}$}} & \multirow{2}{*}{\multicolumn{2}{|c|}{$\begin{array}{c}49.46 \\
0.0092 \\
\end{array}$}} & \multirow{2}{*}{\multicolumn{2}{|c|}{$\begin{array}{c}49.04 \\
0.0066\end{array}$}} & \multirow{2}{*}{\multicolumn{2}{|c|}{$\begin{array}{l}48.77 \\
0.11\end{array}$}} & \multirow{2}{*}{\multicolumn{2}{|c|}{$\begin{array}{l}48.61 \\
0.155\end{array}$}} & \multirow{2}{*}{\multicolumn{2}{|c|}{$\begin{array}{c}48.05 \\
0.1843\end{array}$}} & \multirow{2}{*}{\multicolumn{2}{|c|}{$\begin{array}{r}48.44 \\
0.2144\end{array}$}} & \multirow{2}{*}{\multicolumn{2}{|c|}{$\begin{array}{r}48.41 \\
0.2338\end{array}$}} & \multirow{2}{*}{\multicolumn{2}{|c|}{$\begin{array}{c}48.4 \\
0.265\end{array}$}} & \multirow{2}{*}{\multicolumn{2}{|c|}{$\begin{array}{l}48.37 \\
0.281\end{array}$}} \\
\hline Skewness & & & & & & & & & & & & & & & & & & & & \\
\hline Confidence Interval & Lower & Upper & Lower & Upper & Lower & Upper & Lower & Upper & Lower & Upper & Lower & Upper & Lower & Upper & Lower & Upper & Lower & Upper & Lower & Upper \\
\hline 30 percent & 48.58 & 51.77 & 47.53 & 51.4 & 46.83 & 51.07 & 46.43 & 50.84 & 46.14 & 50.67 & 45.97 & 50.59 & 45.86 & 50.55 & 45.75 & 50.51 & 45.75 & 50.48 & 45.64 & 50.43 \\
\hline 60 percent & 46.51 & 53.46 & 45.15 & 53.66 & 44.28 & 53.69 & 43.76 & 53.69 & 43.42 & 53.68 & 43.21 & 53.65 & 43 & 53.64 & 42.92 & 53.63 & 42.92 & 53.67 & 42.75 & 53.68 \\
\hline 90 percent & 42.83 & 57.14 & 40.86 & 58.15 & 39.59 & 58.83 & 38.79 & 59.34 & 38.39 & 59.68 & 38.03 & 60.01 & 37.82 & 60.3 & 37.62 & 60.56 & 37.62 & 60.84 & 37.36 & 61.04 \\
\hline
\end{tabular}
value in 2025. This shows that, chances of increase in value of M2 in the upcoming forecasted period. 


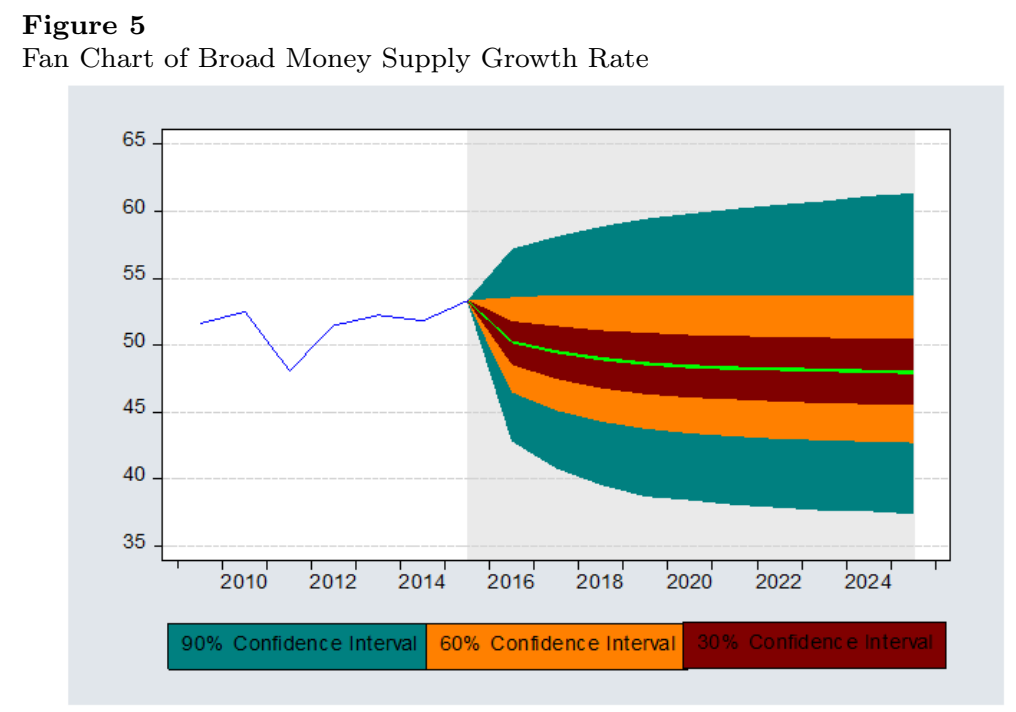

Figure 6 and Table 2 reports the forecasted value of DCP. The average growth rate of DCP expected to be -1.106 percent during the period of 2016 to 2025 . Forecasted value of Skewness will have an upside risk during the all period. Negative growth in DCP could be instability of economic and political environment, which increases the risk. In this scenario tendency of borrowing may be decreased by household and private sector to start new venture, which decrease the growth of DCP.

\section{Figure 6}

Fan Chart of Domestic Credit to Private Growth Rate

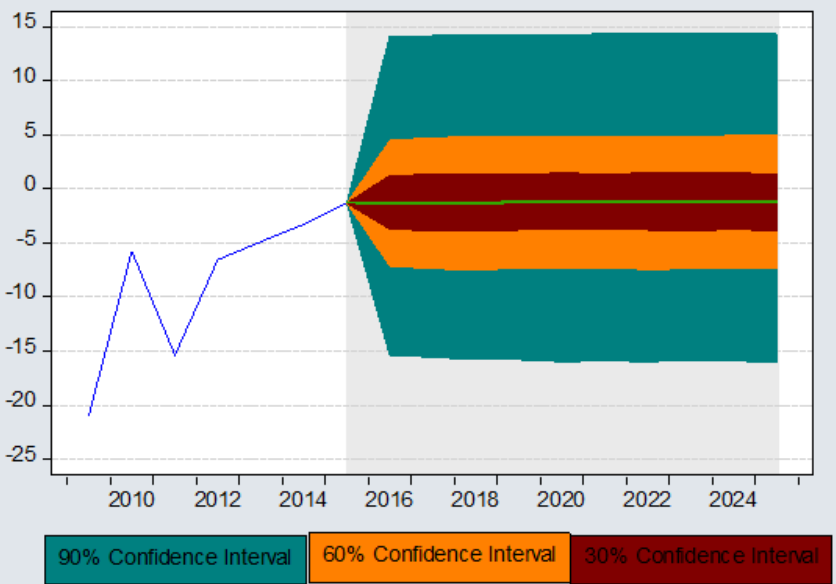


Table 2

Results of Fan Chart of DCP Growth

\begin{tabular}{lcccccccccc}
\hline Year & 2016 & 2017 & 2018 & 2019 & 2020 & 2021 & 2022 & 2023 & 2024 & 2025 \\
\hline DCP Growth & -1.11 & -1.13 & -1.16 & -1.1 & -1.1 & -1.08 & -1.1 & -1.1 & -1.08 & -1.1 \\
Skewness & 0.96 & 0.87 & 0.89 & 0.69 & 1.1 & 0.87 & 0.86 & 0.84 & 0.87 & 0.84 \\
\hline
\end{tabular}

Confidence Interval Lower Upper Lower Upper Lower Upper Lower Upper Lower Upper Lower Upper Lower Upper Lower Upper Lower Upper Lower Upper

\begin{tabular}{|c|c|c|c|c|c|c|c|c|c|c|c|c|c|c|c|c|c|c|}
\hline ent & -3.71 & 1.24 & -3.83 & 1.33 & -3.81 & 1.33 & -3.78 & 1.38 & -3.78 & 1.45 & -3.78 & 1.41 & -3.78 & 1.41 & -3.78 & 1.44 & -3.75 & 1.44 \\
\hline nerc & -7.1 & 4.48 & -7.37 & 4.72 & -7.47 & 4.83 & -7.33 & 4.88 & -7.28 & 4.86 & -7.35 & 4.86 & -7.35 & 4.86 & -7.4 & 4.87 & -7.35 & 4.92 \\
\hline
\end{tabular}

\begin{tabular}{lllllllllllllllllllll}
90 percent & -15.35 & 14.1 & -15.55 & 14.18 & -15.78 & 14.2 & -15.77 & 14.26 & -15.96 & 14.21 & -15.87 & 14.36 & -15.87 & 14.36 & -15.96 & 14.34 & -15.91 & 14.33 & -15.99 & 14.32 \\
\hline
\end{tabular}

Figure 7 and table 3 represents the forecasted value of DCPB. The average growth rate of DCPB will be 20.82 percent during the period of 2016 to 2025. Skewness value indicates a downside risk in the all forecasted period of 2016 to 2025.

\section{Figure 7}

Fan Chart of Domestic Credit to Private by Bank Growth Rate

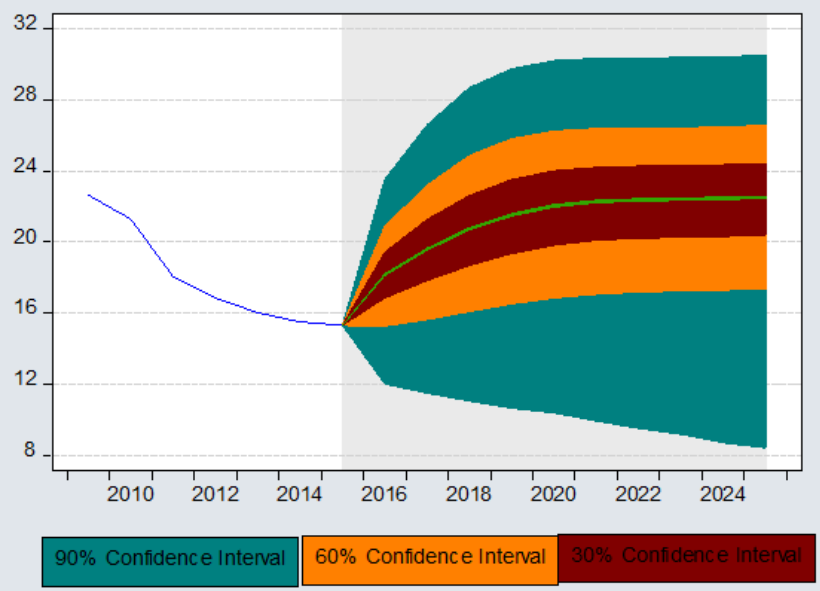

Table 3

Results of Fan Chart of DCPB Growth

\begin{tabular}{lllllllllll}
\hline Year & 2016 & 2017 & 2018 & 2019 & 2020 & 2021 & 2022 & 2023 & 2024 & 2025 \\
\hline DCPB Growth & 18.03 & 19.39 & 20.43 & 21.07 & 21.44 & 21.56 & 21.58 & 21.57 & 21.55 \\
Skewness & -0.18 & -0.18 & -0.25 & -0.36 & -0.47 & -0.57 & -0.65 & -0.69 & -0.76 & -0.79 \\
\hline
\end{tabular}

Confidence Interval Lower Upper Lower Upper Lower Upper Lower Upper Lower Upper Lower Upper Lower Upper Lower Upper Lower Upper Lower Upper

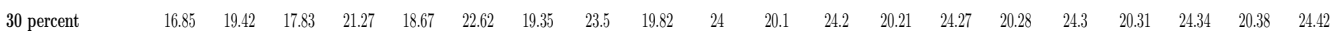

$\begin{array}{lllllllllllllllllllll}60 \text { percent } & 15.26 & 20.89 & 15.63 & 23.21 & 16.08 & 24.86 & 16.52 & 25.81 & 16.84 & 26.24 & 17.06 & 26.39 & 17.19 & 26.41 & 17.24 & 26.41 & 17.3 & 26.47 & 17.34 & 26.56\end{array}$

\begin{tabular}{ccccccccccccccccccccc}
90 percent & 12 & 23.52 & 11.48 & 26.61 & 11.04 & 28.7 & 10.64 & 29.74 & 10.37 & 30.21 & 9.92 & 30.33 & 9.5 & 30.35 & 9.17 & 30.39 & 8.69 & 30.4 & 8.4 & 30.54 \\
\hline
\end{tabular}


Last forecasted value of $\mathrm{MC}$ is showing in Figure 8 and Table 4. Average growth rate of $\mathrm{MC}$ will be 23.96 percent during the period of 2016 to 2025 . Whereas value of Skewness has a downside risk in the same time period.

\section{Figure 8}

Fan Chart of Market Capitalization Growth Rate

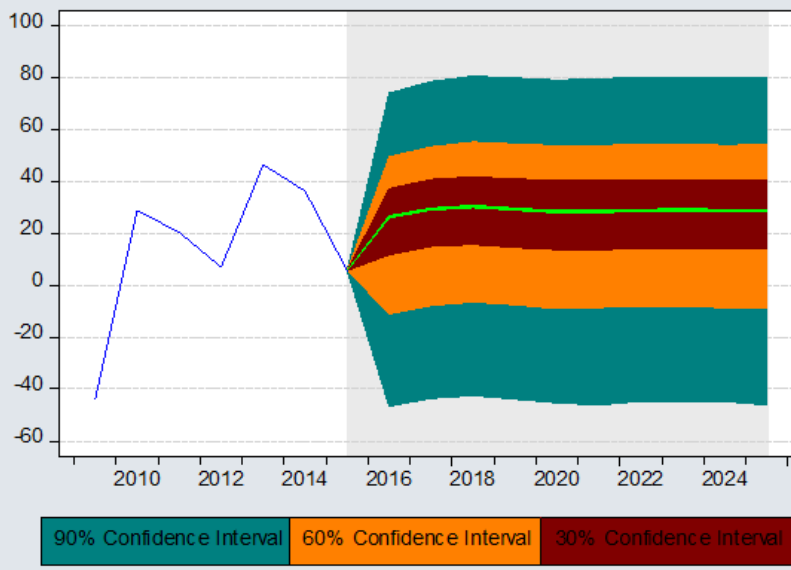

Table 4

Results of Fan Chart of Market Capitalization Growth

\begin{tabular}{lllllllllll}
\hline Year & 2016 & 2017 & 2018 & 2019 & 2020 & 2021 & 2022 & 2023 & 2024 & 2025 \\
\hline MC Growth & 20.95 & 24.38 & 25.64 & 24.63 & 23.65 & 23.71 & 24.28 & 24.26 & 24.15 \\
Skewness & -0.49 & -0.47 & -0.44 & -0.44 & -0.43 & -0.45 & -0.43 & -0.44 & -0.43 & -0.45 \\
\hline
\end{tabular}

Confidence Interval Lower Upper Lower Upper Lower Upper Lower Upper Lower Upper Lower Upper Lower Upper Lower Upper Lower Upper Lower Upper

$\begin{array}{lllllllllllllllllllllll}3 & 30 \text { percent } & 11.71 & 37.2 & 15 & 40.73 & 15.75 & 41.75 & 14.6 & 40.93 & 13.72 & 40.48 & 13.79 & 40.47 & 14.11 & 40.79 & 14.13 & 40.64 & 14.11 & 40.61 & 14.05 & 40.63\end{array}$

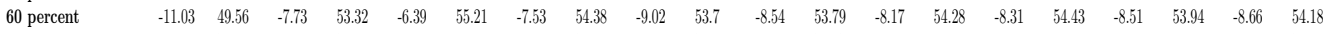

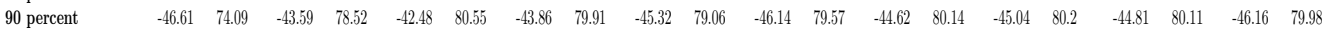

\section{Conclusion and Policy Implications}

This study is conducted to forecast the components of financial development of Pakistan for the period of 2016 to 2025. These components include M2, DCP, DCPB, and MC. Originally, 36 years' time series data taken from 1980 to 2015. The present study is very much different in that it uses a newly developed technique that is Fan chart. It is used to forecast with given level of rang of uncertainty. Risk information of upside and downside is another feature of fan chart approach.

The results of M2 indicate that, downside risk at the start of forecasting in the year of 2016 initially, but after that it will start upside risk in the reaming period of 2017 to highest value in 2025. This shows that, chances to increase in value of M2 in the upcoming forecasted period. On the other side forecasted value of DCP will have an upside risk during 
the all period. Whereas, value of $\mathrm{DCPB}$ indicates a downside risk in the all forecasted period of 2016 to 2025. At the same time, value of MC has a downside risk in the all-time period. These results also propose a reasonable consideration of uncertainty linked with all the forecasted components of FDI. On the basis of these findings, it is recommended to policy makers to keep a diligent eye on downside risk of DCPB and MC. Downside risk is an alarming situation in the coming years or the uncertainty around to the extent of that change. Upside risk should also be considered by the policy maker for DCP. Upside risk is the uncertainty with opportunity of improvement in the future. The policy implications is to control and retain the downside risk in the context of market capitalization of Pakistan. Whereas, growth of MC is 23.69 percent in the forecasted period of 2016-2025.

The policy implication of this investigation is consequently clear. It is evident to build a strong monetary policy to strengthen the features of central bank and also put efforts carefully to increase competitive financial environment in the market. Side by side, to extend the financial division, upgrade the intensity of money and capital markets, construct solid institutional and administrative system that will make capital mobility to incorporate financial system in a country. The central bank should also provide the conducive environment to encourage financial inclusion to develop financial development in a country. This will provide less risky financial environment in the country.

Therefore, this research is comprehended as a directorial step towards enhanced practice and further empirical research in this field. The above discussed risk and uncertainty is one of the area of research, but further analysis of different regions or groups' financial development could be done. This study is done on the component of financial development, therefore it will help to analysis these component?s role to calculate the financial development. 


\section{References}

Abbasi, F., \& Riaz, K. (2016). CO2 emissions and financial development in an emerging economy: An augmented VAR approach. Energy Policy, 90, 102-114.

Adu, G., Marbuah, G., \& Mensah, J. T. (2013). Financial development and economic growth in Ghana: Does the measure of financial development matter? Review of Development Finance, 3(4), 192-203.

Akram, Q. F., Binning, A., \& Maih, J. (2016). Joint prediction bands for macroeconomic risk management.

Anwar, S., \& Cooray, A. (2012). Financial development, political rights, civil liberties and economic growth: Evidence from South Asia. Economic Modelling, 29(3), 974-981.

Asongu, S. A., Koomson, I., \& Tchamyou, V. S. (2017). Financial globalisation uncertainty/instability is good for financial development. Research in International Business and Finance, 41, 280-291.

Atje, R., \& Jovanovic, B. (1993). Stock markets and development. European Economic Review, 37(2-3), 632-640.

Bagehot, W. (1873). Lombard street: A description of the money market. Scribner, Armstrong \& Company.

Beck, T., \& Levine, R. (2004). Stock markets, banks, and growth: Panel evidence. Journal of Banking \& Finance, 28(3), 423-442.

Bekaert, G., Hoerova, M., \& Duca, M. L. (2013). Risk, uncertainty and monetary policy. Journal of Monetary Economics, 60(7), 771-788.

Black, L., Correa, R., Huang, X., \& Zhou, H. (2016). The systemic risk of European banks during the financial and sovereign debt crises. Journal of Banking $\&$ Finance, 63, $107-125$.

Blix, M., \& Sellin, P. (1998). Uncertainty bands for inflation forecasts (Tech. Rep.). Sveriges Riksbank Working Paper No 65.

Bloom, N., Bond, S., \& Van Reenen, J. (2007). Uncertainty and investment dynamics. The Review of Economic Studies, 74 (2), 391-415.

Caldara, D., Fuentes-Albero, C., Gilchrist, S., \& Zakrajšek, E. (2016). The macroeconomic impact of financial and uncertainty shocks. European Economic Review, 88, 185207.

Camilleri, G., \& Vella, K. (2015). Interpolating forecast errors for assess-ing uncertainty in macroeconomic fore-casts: An analysis for malta.

Castillo, M. A. (2016). Template for external sustainability assessment (Tech. Rep.). Inter-American Development Bank.

Chakraborty, I. (2010). Financial development and economic growth in India: An analysis of the post-reform period. South Asia Economic Journal, 11(2), 287-308.

Cole, R. A., Moshirian, F., \& Wu, Q. (2008). Bank stock returns and economic growth. Journal of Banking \& Finance, 32(6), 995-1007.

De Luna, X. (2000). Prediction intervals based on autoregression forecasts. Journal of the Royal Statistical Society: Series D (The Statistician), 49(1), 87-93.

Dowd, K., Blake, D., \& Cairns, A. J. (2016). The myth of methuselah and the uncertainty of death: The mortality fan charts. Risks, 4(3), 1-7. 
Duarte, L. d. R. V., Kedong, Y., \& Xuemei, L. (2017). The relationship between fdi, economic growth and financial development in cabo verde. International Journal of Economics and Finance, 9(5), 132.

Fukač, M., \& Kirkby, R. (2017). Accounting for uncertainty in public debt targets. Australian Economic Review, 50(1), 89-102.

Fuller, W. A., \& Hasza, D. P. (1981). Properties of predictors for autoregressive time series. Journal of the American Statistical Association, 76(373), 155-161.

Giedeman, D., Compton, R., et al. (2009). A note on finance, inflation, and economic growth. Economics Bulletin, 29(2), 749-759.

Gokmenoglu, K. K., Amin, M. Y., \& Taspinar, N. (2015). The relationship among international trade, financial development and economic growth: The case of Pakistan. Procedia Economics and Finance, 25, 489-496.

Hakeem, M., \& Oluitan, O. (2012). Financial development and human capital in South Africa: A time-series approach. Research in Applied Economics, 4(3), 18-38.

Holod, D., Kitsul, Y., \& Torna, G. (2017). Market risk-based capital requirements, trading activity, and bank risk. Journal of Banking $\&$ Finance.

Hsueh, S.-J., Hu, Y.-H., \& Tu, C.-H. (2013). Economic growth and financial development in Asian countries: A bootstrap panel granger causality analysis. Economic Modelling, 32, 294-301.

Hussain, F. (2005). Monetary aggregates in Pakistan: Theoretical and empirical underpinnings.

Iqbal, J. (2012). Stock market in pakistan: An overview. Journal of Emerging Market Finance, 11(1), 61-91.

Javid, M., \& Sharif, F. (2016). Environmental Kuznets curve and financial development in Pakistan. Renewable and Sustainable Energy Reviews, 54, 406-414.

Jawaid, S. T., Waheed, A., et al. (2017). Uncertainty and risk analysis of Pakistan's regional trade: Fan chart approach. Journal of Management Sciences, 4 (1), 55-81.

Kakar, Z. K., Khilji, B. A., \& Khan, M. J. (2011). Financial development and energy consumption: Empirical evidence from Pakistan. International Journal of Trade, Economics and Finance, 2(6), 469-471.

Kannan, P., \& Elekdag, S. (2009). Incorporating market information into the construction of the fan chart (No. 9-178). International Monetary Fund.

Khan, M. A., Qayyum, A., Sheikh, S. A., \& Siddique, O. (2005). Financial development and economic growth: The case of Pakistan. The Pakistan Development Review, 819-837.

Kitagawa, N., \& Okuda, S. (2016). Management forecasts, idiosyncratic risk, and the information environment. The International Journal of Accounting, 51(4), 487-503.

Komal, R., \& Abbas, F. (2015). Linking financial development, economic growth and energy consumption in Pakistan. Renewable and Sustainable Energy Reviews, 44, 211-220.

Kose, M. A., Prasad, E. S., \& Taylor, A. D. (2009). Thresholds in the process of international financial integration (Vol. 30) (No. 1). The World Bank.

Latif, A., Nazar, M. S., Shah, M. Z., \& Shaikh, F. M. (2011). Global financial crisis: Macroeconomic linkage to Pakistan's agriculture. Asian Social Science, 7(7), 90. 
Levine, R. (2005). Finance and growth: Theory and evidence. Handbook of Economic Growth, 1, 865-934.

Mahmood, A. (2013). Impact of financial development on economic growth of pakistan. Abasyn Journal of Social Sciences, 6(2), 106-116.

Moshirian, F. (2011). The global financial crisis and the evolution of markets, institutions and regulation. Journal of Banking \& Finance, 35(3), 502-511.

Nik, H., Nasab, Z., Salmani, Y., \& Shahriari, N. (2013). The relationship between financial development indicators and human capital in Iran. Management Science Letters, $3(4), 1261-1272$.

Outreville, J. F. (1999). Financial development, human capital and political stability. United Nations Conference on Trade and Development..

Reinhart, C. M. (2000). Mirage of floating exchange rates. American Economic Review, $90(2), 65-70$.

Rizwan-ul Hassan, M., Imam, S. G., \& Salim, S. (2017). Analyzing the effects of financial development on economic growth: Empirical evidence from Pakistan through PCA approach. Abasyn University Journal of Social Sciences, 10(2).

Rodrik, D., \& Subramanian, A. (2009). Why did financial globalization disappoint? IMF Staff Papers, 56(1), 112-138.

Sehrawat, M., \& Giri, A. (2017). An empirical relationship between financial development indicators and human capital in some selected Asian countries. International Journal of Social Economics, $44(3), 337-349$.

Shahbaz, M., Ahmed, N., \& Ali, L. (2008). Stock market development and economic growth: ARDL causality in Pakistan. International Research Journal of Finance and Economics, 14(1), 182-195.

Shahbaz, M., \& Rahman, M. M. (2012). The dynamic of financial development, imports, foreign direct investment and economic growth: cointegration and causality analysis in Pakistan. Global Business Review, 13(2), 201-219.

Shen, C.-H., \& Lee, C.-C. (2006). Same financial development yet different economic growth: Why? Journal of Money, Credit and Banking, 38(7), 1907-1944.

Valencia, F. (2017). Aggregate uncertainty and the supply of credit. Journal of Banking EG Finance, 81, 150-165.

Valickova, P., Havranek, T., \& Horvath, R. (2015). Financial development and economic growth: A meta-analysis. Journal of Economic Surveys, 29(3), 506-526.

$\mathrm{Yu}, \mathrm{H}$. (2011). Uncertainty and risk analysis of the langrun Chinese GDP forecast: Fan charts revisited. China Economic Journal, 4(2-3), 81-104.

Yu, J.-S., Hassan, M. K., \& Sanchez, B. (2012). A re-examination of financial development, stock markets development and economic growth. Applied Economics, 44 (27), 34793489 . 